\title{
Research on the effect of Fujian free trade zone to Xiamen international shipping center
}

\author{
Li Zhang ${ }^{1, a}$, Jie Zhu ${ }^{2}$ and Dan Liu ${ }^{3}$ \\ ${ }^{1}$ Department of Logistics, Fuzhou University of International Studies and Trade, Fuzhou, China \\ ${ }^{2}$ Department of Scientific Research, Fuzhou University of International Studies and Trade, Fuzhou, China \\ ${ }^{3}$ Department of Logistics, Fuzhou University of International Studies and Trade, Fuzhou, China
}

\begin{abstract}
China free trade zone is an important carrier of the Belt and Road to achieve the internal and external linkage. There are four free trade zones in china. They are in Shanghai, Guangdong, Tianjin and Fujian. Fujian free trade zone supplies greater openness and favorable policies for Xiamen international shipping center, and dispenses with the formalities, reduces shipping costs, and realizes the territory of the commissioner of policies. So it will be in favor of FDI and benefited for employment-generating. It will boost the economy and increase international trade. Firstly this paper found out the influence factors of Fujian free trade zone to Xiamen international shipping center through the investigation. Then index system of these influencing factors was designed. And then the index system was designed into a questionnaire. Relevant experts filled the questionnaire. Then the main influence factors and secondary influence factors were been found. The weights of each index were got by using the method of analytic hierarchy. At last, development strategies of Xiamen international shipping center were been proposed.
\end{abstract}

\section{Introduction}

Prime Minister Keqiang Li proposed that set a free trade zone in Fujian in2014. Fujian free trade zone has a total area of 118.04 square meters including Fuzhou, Pingtan, Xiamen three places. With the introduction of preferential policies in Fujian Province, Fujian free trade zone will attract more consumer groups and more foreign goods to the Fujian free trade zone and transit. International Trade and financial flows will be freer in Fujian free trade zone [1]. Xiamen international shipping center will get support for the volume of trade, national policy, infrastructure, financial services and other aspects.

Fujian free trade zone has played a huge role in supporting Xiamen international shipping center. This paper focuses on the impact of Fujian free trade zone on Xiamen international shipping center. Firstly, the index system of Fujian free trade zone to Xiamen international shipping center was established. Three first level indicators were constructed. They are shipping level, shipping services and shipping ecology. Three first level indicators contain 17 second grade indexes. Secondly, the index system was

\footnotetext{
${ }^{\mathrm{a}}$ Corresponding author : 415613585@qq.com
} 
set up into a questionnaire which the experts filled in. The data was collected by expert survey. With the AHP method of data processing, the weights of the indicators were got. Finally, suggestions on the construction of Xiamen international shipping center were put forward.

\section{Methodology}

\subsection{Analytic hierarchy process theory}

Analytic hierarchy process is a kind of hierarchical weight decision analysis method which applies network system theory and multi objective comprehensive evaluation method. In this paper, the AHP hierarchy model is built in a progressive system structure with $\mathrm{M}$ layer. There is only one factor in the top level. The factors of the next layer belong to the upper layer. The different factors in the same layer are parallel. There is no direct relationship between the two adjacent factors [2]. In any one of the index system, the meaning of each factor is different and the social problems described by the index system are different. So the total index values are a relation of weighted sum, but not simply add the various indicators of the system factors. Specific models such as formula1:

$$
S=\sum_{i=1}^{n} W_{i} f_{i}\left(I_{i}\right) \quad i=1,2, \ldots \ldots, \quad n
$$

Among them, $f_{i}\left(I_{i}\right)$ is a function of $I_{i}$. $W_{i}$ represents the weight of each indicator.

\subsection{Steps of analytic hierarchy process}

\subsubsection{Structure judgment matrix}

The importance degree of each factor can be got by the comparison between two factors of each level. According to the degree of importance, the level of each factor can be rated. The comparison result is the judgment matrix. Saaty gave 9 importance levels and their assignment as shown in Table 1. $B$ indicates the judgment matrix $b_{i j}$ indicates the comparison between the two factors. $b_{i j}$ is identified based on expert opinion and system analyst repeated studies.

Table 1. The meaning of importance scale.

\begin{tabular}{l|l}
\hline quantized value & comparison between the two factors \\
\hline 1 & equally important \\
3 & slightly important \\
5 & extremely important \\
7 & Strongly important \\
9 & crucial importance \\
$2,4,6,8$ & The middle value of two adjacent assignment \\
\hline
\end{tabular}

\subsubsection{Calculating Weighting Vector}

For the constructing judgment matrix, the eigenvectors which matched largest eigenvalueis are calculated. The relative weight of each factor in the index system is obtained after normalized the eigenvectors. Take solving the judgment matrix $M$ as an example:

$$
H W=\lambda W
$$


Among them, $M$ represents the judgment matrix, $W$ represents the eigenvectors. $\lambda_{\max }$ and $W$ are solved out and $W$ is normalized. Then the weights of each factor are got. Weight indicates the relative importance of a low level to a higher level.

\subsubsection{Consistency check}

When applying analytic hierarchy process, it is very important to keep the consistency of judgment thinking. If the judgment matrix satisfies the formula 3,4 and 5 , the judgment matrix is consistent.

$$
\begin{gathered}
b_{i i}=1 \\
b_{j i}=1 / b_{i j} \\
b_{i j}=b_{i k} / b_{j k}
\end{gathered}
$$

Among them, $i, j, k=1,2, \ldots . ., n$

The consistency index of judgment matrix:

$$
\mathrm{CI}=\frac{\lambda_{\max }-n}{n-1}
$$

The greater the value of the consistency index $\mathrm{CI}$ is, the more inconsistent the judgment matrix is. The smaller the value of the consistency index CI is, the more consistent the judgment matrix is. For multi-step judgment matrix, it can be tested by used the average random consistency index RI. The average random consistency index which is gotten by 1-10 step matrix calculation after 1000 times is given in the table 2 .

Table 2. The average random consistency index.

\begin{tabular}{lllllllllll}
\hline $\mathrm{n}$ & 1 & 2 & 3 & 4 & 5 & 6 & 7 & 8 & 9 & 10 \\
$\mathrm{RI}$ & 0 & 0 & 0.58 & 0.90 & 1.12 & 1.24 & 1.32 & 1.41 & 1.46 & 1.49 \\
\hline
\end{tabular}

When $n \leq 2$, judgment matrix is always consistent. The ratio of judgment matrix consistency index $\mathrm{CI}$ and average random consistency index RI is called the random consistency ratio CR.

$$
C R=\frac{C I}{R I}
$$

When $C R<0.1$, it is believed that the consistency of judgment matrix can be accepted. When $C R>0.1$, the consistency cannot be accepted. It is necessary to modify the judgment matrix in order to achieve acceptable consistency. In order to make the evaluation result of the index system is correct, the consistency check of each judgment matrix must be carried out in the analytic hierarchy process.

\section{Data analysis and results}

\subsection{Impact index system of Fujian Free Trade Zone on Xiamen international shipping center}




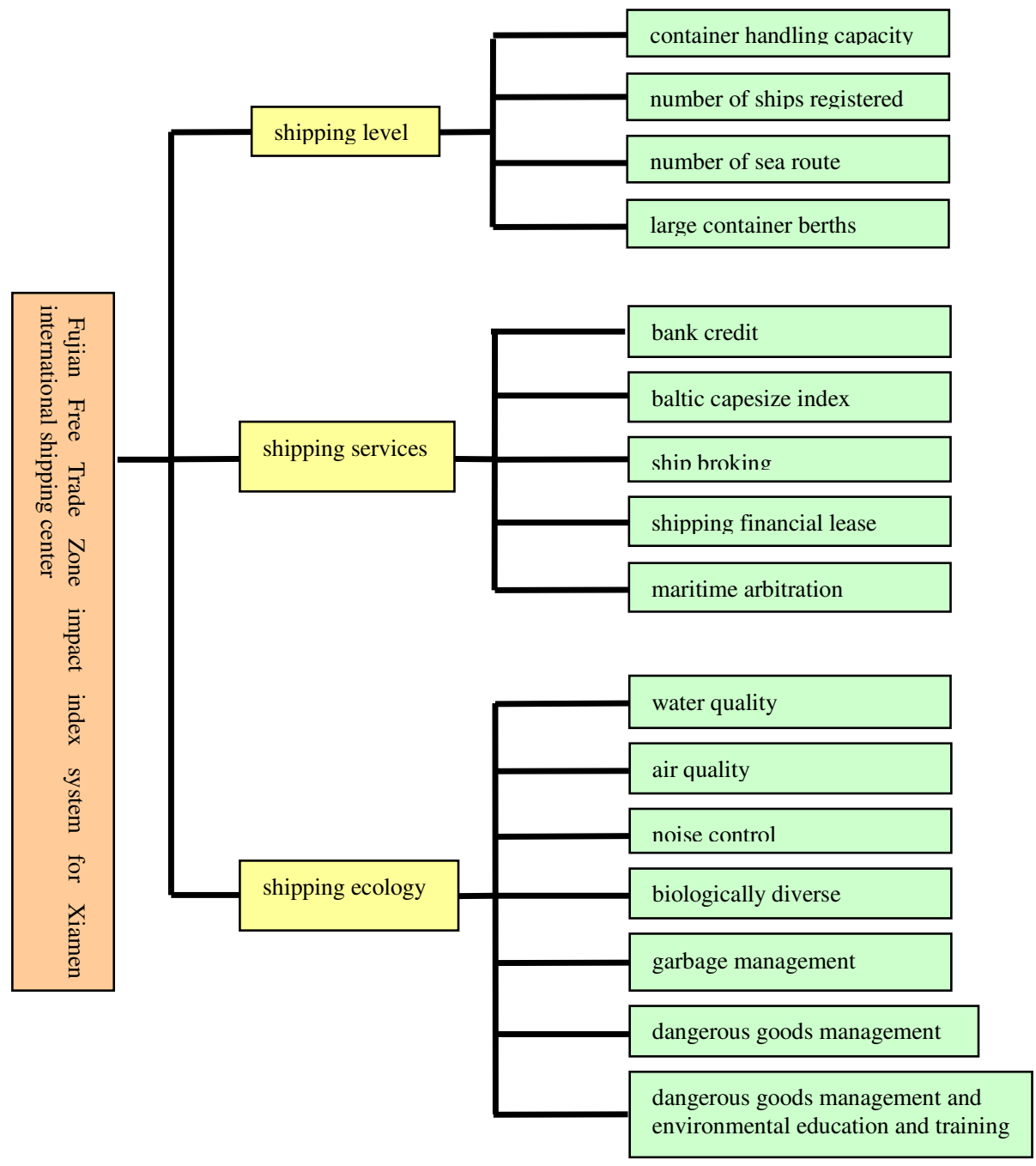

Figure 1. Fujian Free Trade Zone impact index system for Xiamen international shipping center.

Xiamen international shipping center covers an area of 24.41 square kilometers. It is Xiamen port hub, shipping and trading center and service enterprise gathering center. The geographical position of Xiamen port is excellent. It is port of navigation routes which the north and south route to the Yangtze River Delta and the Pearl River Delta must pass through in our country. The west coast of Taiwan Strait can be arrived direct from Xiamen port. Compared with other ports, Xiamen port spents less time, navigates the shortest route distance and costs the lowest money. The combination of 200 thousand ton container ship and 150 thousand ton container ship can full tidal and two-way navigate in the whole channel of Xiamen port. At the same time, it can meet the two-way navigation requirement of the 200 thousand ton container ships which have a draught of 15.5 metres.

According to "the fourth generation international shipping center" innovation mode, the competitiveness of international shipping center has been assessed and evaluated. Based on the Global international Shipping-Center Index, this paper established a two level index system to study the influence of Fujian Free Trade Zone on Xiamen international shipping center. There are 3 one class indexes. And one class index sets target of 162 class. One class indexes contain shipping level, shipping services and shipping ecology. Shipping level sets target of 42 class. They are container 
handling capacity, number of ships registered, number of sea route and large container berths. Shipping services set target of 52 class. They are bank credit, baltic capesize index, ship broking, shipping financial lease and maritime arbitration. Shipping ecology sets target of 72 class. They are water quality, air quality, noise control, biologically diverse, garbage management, dangerous goods management and environmental education and training. It is shown in figure 1.

\subsection{Applying the method of AHP to confirm the index weight}

According to impact index system of Fujian Free Trade Zone on Xiamen international shipping center which is constructed above, expert questionnaire was compiled. Based on the 9 importance rating method given by Saaty, experts gave each index scoring. After getting the experimental data, several judgment matrixes were constructed. Judgment matrixes were calculated by using the yaaph software of analytic hierarchy process, and the weight of each index is obtained. Then whether the judgment matrix satisfied the consistency index was tested. The judgment matrix and weight of one class indexes are shown in table 3.

Table 3. The judgment matrix and weight of one class indexes.

\begin{tabular}{lllll}
\hline index & Shipping level & Shipping services & Shipping ecology & weight $W_{i}$ \\
\hline Shipping level & 1.0000 & 2 & 3 & 0.5396 \\
Shipping services & 0.5000 & 1.0000 & 2 & 0.2970 \\
Shipping ecology & 0.3333 & 0.5000 & 1.0000 & 0.1634 \\
\hline
\end{tabular}

The consistency ratio of the one class index judgment matrix is 0.0088 . So the judgment matrix passed the consistency tests. We can draw a conclusion from the obtained weight values that shipping level is the biggest impact influence of Fujian Free Trade Zone on Xiamen international shipping center, followed by the shipping services, and finally the shipping ecology. The judgment matrix and weight of shipping level index are shown in table 4.

Table 4. The judgment matrix and weight of shipping level index.

\begin{tabular}{llllll}
\hline index & $\begin{array}{l}\text { container } \\
\text { handling } \\
\text { capacity }\end{array}$ & $\begin{array}{l}\text { number of } \\
\text { ships } \\
\text { registered }\end{array}$ & $\begin{array}{l}\text { number of sea } \\
\text { route }\end{array}$ & $\begin{array}{l}\text { large } \\
\text { container } \\
\text { berths }\end{array}$ & $\begin{array}{l}\text { weight } \\
W_{i}\end{array}$ \\
\hline $\begin{array}{l}\text { container handling } \\
\text { capacity }\end{array}$ & 1.0000 & 3.0000 & 4.0000 & 2.0000 & 0.4747 \\
$\begin{array}{l}\text { number of ships } \\
\text { registered }\end{array}$ & 0.3333 & 1.0000 & 3.0000 & 3.0000 & 0.2551 \\
$\begin{array}{l}\text { number of sea route } \\
\text { large container berths }\end{array}$ & 0.2500 & 0.5000 & 1.0000 & 0.5000 & 0.1072 \\
\hline
\end{tabular}

Table 5. The judgment matrix and weight of shipping services index.

\begin{tabular}{lllllll}
\hline index & $\begin{array}{l}\text { bank } \\
\text { credit }\end{array}$ & $\begin{array}{l}\text { baltic } \\
\text { capesize } \\
\text { index }\end{array}$ & $\begin{array}{l}\text { ship } \\
\text { broking }\end{array}$ & $\begin{array}{l}\text { shipping } \\
\text { financial } \\
\text { lease }\end{array}$ & $\begin{array}{l}\text { maritime } \\
\text { arbitration }\end{array}$ & $\begin{array}{l}\text { weight } \\
W_{i}\end{array}$ \\
\hline $\begin{array}{l}\text { bank credit } \\
\text { baltic capesize }\end{array}$ & 1.0000 & 0.2500 & 1.0000 & 2.0000 & 0.3333 & 0.1160 \\
$\begin{array}{l}\text { index } \\
\text { ship broking }\end{array}$ & 4.0000 & 1.0000 & 4.0000 & 4.0000 & 2.0000 & 0.4379 \\
$\begin{array}{l}\text { shipping financial } \\
\text { lease } \\
\text { maritime }\end{array}$ & 1.0000 & 0.2500 & 1.0000 & 2.0000 & 0.5000 & 0.1258 \\
arbitration & 0.5000 & 0.2500 & 0.5000 & 1.0000 & 0.5000 & 0.0830 \\
\hline
\end{tabular}


The consistency ratio of the shipping level index judgment matrix is 0.0871 . So the judgment matrix passed the consistency tests. We can draw a conclusion from the obtained weight values that container handling capacity is the biggest impact influence in the shipping level index, followed by number of ships registered, large container berths, and finally number of sea route. The judgment matrix and weight of shipping services index are shown in table 5.

The consistency ratio of the shipping services index judgment matrix is 0.0268 . So the judgment matrix passed the consistency tests. We can draw a conclusion from the obtained weight values that baltic capesize index is the biggest impact influence in the shipping services index, followed by maritime arbitration, ship broking, bank credit, and finally shipping financial lease. The judgment matrix and weight of shipping ecology index are shown in table 6.

Table 6. The judgment matrix and weight of shipping ecology index.

\begin{tabular}{|c|c|c|c|c|c|c|c|c|}
\hline index & $\begin{array}{l}\text { water } \\
\text { quality }\end{array}$ & $\begin{array}{l}\text { air } \\
\text { quality }\end{array}$ & $\begin{array}{l}\text { noise } \\
\text { control }\end{array}$ & $\begin{array}{l}\text { biologica } \\
\text { diverse }\end{array}$ & $\begin{array}{l}\text { garbage } \\
\text { management }\end{array}$ & $\begin{array}{l}\text { dangerous } \\
\text { goods } \\
\text { management }\end{array}$ & $\begin{array}{l}\text { environmental } \\
\text { education and } \\
\text { training }\end{array}$ & $\begin{array}{l}\text { weight } \\
W_{i}\end{array}$ \\
\hline water quality & 1.0000 & 3.0000 & 4.0000 & 3.0000 & 2.0000 & 2.0000 & 5.0000 & 0.3041 \\
\hline air quality & 0.3333 & 1.0000 & 2.0000 & 0.5000 & 0.3333 & 0.5000 & 0.5000 & 0.0712 \\
\hline noise control & 0.2500 & 0.5000 & 1.0000 & 0.3333 & 0.3333 & 0.3333 & 1.0000 & 0.0551 \\
\hline $\begin{array}{l}\text { biologically } \\
\text { diverse }\end{array}$ & 0.3333 & 2.0000 & 3.0000 & 1.0000 & 0.5000 & 0.3333 & 2.0000 & 0.1121 \\
\hline $\begin{array}{l}\text { garbage } \\
\text { management } \\
\text { dangerous }\end{array}$ & 0.5000 & 3.0000 & 3.0000 & 2.0000 & 1.0000 & 0.5000 & 3.0000 & 0.1723 \\
\hline $\begin{array}{l}\text { goods } \\
\text { management }\end{array}$ & 0.5000 & 2.0000 & 3.0000 & 3.0000 & 2.0000 & 1.0000 & 4.0000 & 0.2189 \\
\hline $\begin{array}{l}\text { environmental } \\
\text { education and } \\
\text { training }\end{array}$ & 0.2000 & 2.0000 & 1.0000 & 0.5000 & 0.3333 & 0.2500 & 1.0000 & 0.0662 \\
\hline
\end{tabular}

The consistency ratio of the shipping ecology index judgment matrix is 0.0406 . So the judgment matrix passed the consistency tests. We can draw a conclusion from the obtained weight values that water quality is the biggest impact influence in the shipping ecology index, followed by dangerous goods management, garbage management, biologically diverse, air quality, environmental education and training, and finally noise control.

\section{Conclusion}

This paper established the impact index system of Fujian free trade zone to Xiamen international shipping center. It can be seen that the important impact factors of Fujian Free Trade Zone on the Xiamen international shipping center are container handling capacity, number of ships registered and baltic capesize index.

\section{Acknowledgement}

Funding from Fujian province education scientific research project of the education of young teachers (NO: JAS150703) supported this research.

\section{References}

1. S. Liu and Y. Zhu, International Trade, 7, 87-89 (2015)

2. Q. Zhang, Logistics technology, 34, 11-14 (2015) 